\title{
Scenario of land use and land cover change in the Gaza Strip using remote sensing and GIS models
}

\author{
Basheer Abuelaish $^{1}$ (iD $\cdot$ María Teresa Camacho Olmedo $^{2}$
}

Received: 27 December 2014 / Accepted: 28 December 2015 /Published online: 28 March 2016

(C) The Author(s) 2016. This article is published with open access at Springerlink.com

\begin{abstract}
Land use and land cover change is a major global environmental change issue, and projecting changes are essential for the assessment of the environment. The Gaza Strip will have grown over 2.4 million inhabitants by 2023, and the land demands will exceed the sustainable capacity of land use by far. Land use planning is one of the most difficult issues in the Gaza Strip given that this area is too small. Continuous urban and industrial growth will place additional stress on land cover, unless appropriate integrated planning and management actions are instituted immediately. Planners need further statistics and estimation tools to achieve their vision for the future based on sound information. Therefore, this study combines the use of satellite remote sensing with geographic information systems (GISs). The spatial database is developed by using five Landsat images gathered in 1972, 1982, 1990, 2002 and 2013. Three GIS models are selected for simulation by the year 2023: Geomod, CA_Markov and Land Change Modeler using Idrisi Selva. The projected urban area will have undergone an increase of $212.3 \mathrm{~km}^{2}$ by the year 2023 in the used models, and the percentage of urban area will account for $58.83 \%$ of the Gaza strip by 2023 .
\end{abstract}

Keywords Land use and land cover change $\cdot$ Scenario . Urban · Geomod ·CA_Markov · Land Change Modeler

Basheer Abuelaish

babuelaish@gmail.com

María Teresa Camacho Olmedo camacho@ugr.es

1 Department of GIS, Environment Quality Authority, Gaza, Palestine

2 Departamento de Análisis Geográfico Regional y Geografía Física, University of Granada, Granada, Spain

\section{Introduction}

The population of the Gaza Strip will have grown over two million by 2020 , with the growth population rate at $3.44 \%$ in 2013(PCBS 2013). The demand of land will exceed the sustainable capacity of land use by far. The continuous urban growth and the implementation of different projects will place additional stress on land cover, unless appropriate integrated planning and management actions are instituted immediately.

There have been severe changes in the vegetation cover in most of the Gaza Strip. The effects of limited natural resources coupled with a high population growth have posed many environmental challenges. The limited water resources, heavy application of fertilisers and pesticides, inappropriate agricultural practices and overgrazing have produced much of the desertification features that are now prominent over the past years and could be irreversible in many parts of the Gaza Strip.

These conditions have a significant impact on land fertility decline. In order to overcome this deep deterioration, the Palestinian Environment Strategy considered 11 elements, namely, wastewater management, water resources management, solid waste management, agricultural and irrigation management, industrial pollution control, land use planning, public information and awareness, monitoring and database management, environmental standards, some thematic issues and international political issues (MEnA 1999).

Many human and natural factors in the Gaza Strip have led to various types of pressures on the land, resulting in the degradation of land quality and quantity.

The Gaza Strip has been a theatre of conflict for decades. Each of these conflicts has left its mark, and over time, a significant environmental footprint has developed in the Gaza Strip (UNEP 2009).

Land use and land cover change (LUCC) is a key driver of global environmental change and has important implications 
for many national and international policy issues (Nunes and Augé 1999; Lambin et al. 2001) indicating that the impacts of land use and land cover change are critical to many governmental programmes such as documenting the rates, driving forces and consequences of change. Land use/land cover change is often related to land planning, food watch and urban growth (Paegelow and Camacho 2008). In developing countries, urban sprawl is worsened by the lack of land use planning (Jat et al. 2008; Bayramoglu and Gundogmus 2008; Han et al. 2009; Biggs et al. 2010; Lee and Choe 2011).

Remote sensing as a monitoring technique is very useful to achieve the required data for land use changes, urban planning, urban sprawl and other environmental issues. This leads to the need for monitoring by updating the knowledge to support the decision making, at suitably intervals. Monitoring of land use and land cover requires the support of two parameters: spatial resolution and temporal frequencies (Curran 1985; Janssen 1993; Hualou et al. 2007).

Satellite imagery provides an excellent source of data for performing landscape structural studies. Simple pattern measurements, such as the number, size and shape of patches, can indicate more about the functionality of a land cover type than the total area of cover alone (Forman 1995). When fragmentation statistics are compared across time, they are useful in describing the type of land cover change and indicating the resulting impact on the surrounding habitat. The areas of land cover change between images can also be compared to landscape characteristics to determine if change is more likely to occur in the presence of certain environmental and humaninduced factors. This level of classification detail presents opportunities to analyse land cover change patterns at a structural scale (Gerylo et al. 2000).

Fung (1990) indicated that the techniques and methods of using satellite imageries as data sources have been developed and successfully applied for land use classification and change detection in various environments including rural, urban and urban fringes. Satellite-based remote sensing technology cannot yet be used to monitor land use at the level of accuracy required by developers, engineers and planners' interests.

Modelling can be defined in the context of geographic information systems (GISs) as occurring whenever operations of the GISs attempt to emulate processing the real world, at one point in time or over an extended period (Goodchild 2005; Paegelow et al. 2013). GIS models go further to evaluate the future and are used to assess different scenarios, depending on the historical data which are retrieved from multiple resources.

Scenarios have emerged as useful tools to explore uncertain futures in ecological and anthropogenic systems (Sleeter et al. 2012). Scenarios typically lack quantified probabilities (Nakicenovic and Swart 2000; Swart et al. 2004), instead functioning as alternative narratives or storylines that capture important elements about the future (Nakicenovic and Swart 2000; Peterson et al. 2003; Swart et al. 2004). Alcamo et al.
(2008, p. 15) define scenarios as "descriptions of how the future may unfold based on 'if-then' propositions." Scenarios are used to assist in the understanding of possible future developments in complex systems that typically have high levels of scientific uncertainty (Nakicenovic and Swart 2000; Raskin et al. 1998).

Very few studies deal with land cover change in the Gaza strip without determining the percentage of land degradation. The MedWetCoast project (2003) studied land use planning in Wadi Gaza (Gaza Valley) using GIS and remote sensing, and the UNEP studied the destroyed areas during the conflict in 2002 in the north and south of the Gaza Strip by using remote sensing(UNEP 2003).

This study aimed to analyse urban growth data, the expansion of the urban mass in the Gaza Strip and the impact of this growth on land use and land cover changes, as important future driver of water quality, food safety and climate change. One past trend scenario and models are used within GIS techniques and remote sensing data, in order to identify the plots of the future of Gazans in 2023 that can be useful for decision makers.

In this paper, we will present the study area, and the methodology including land change analysis, simulation and modelling. Finally, we will present the results, discussion and conclusions.

\section{Study area}

The Gaza Strip is a narrow area on the Mediterranean coast. It borders Israel to the east and north and Egypt to the south. It is approximately $41 \mathrm{~km}$ long, and between 6 to $12 \mathrm{~km}$ wide, with a total area of $365 \mathrm{~km}^{2}$ as shown in Fig. 1.

The Gaza Strip has a temperate climate, with mild winters and dry, hot summers subject to drought. Average rainfall is of about $300 \mathrm{~mm}$ (MOAg 2013). The terrain is flat or rolling, with dunes near the coast. The highest point is $105 \mathrm{~m}$ above sea level. There are no permanent water bodies in the Gaza Strip.

In 1948, the Gaza Strip had a population of less than 100, 000 people (Ennab 1994). By 2007, approximately 1.4 million Palestinians lived in the Gaza Strip, of whom almost 1 million were UN-registered refugees.

The current population in 2013 is estimated to be in excess of 1.7 million, distributed across five governorates (PCBS 2013). Gaza City, which is the biggest governorate, has some 588,033 inhabitants. The two other main governorates are Khan Younisand Rafah, where the population is of some 320,835 and 210,166 inhabitants, respectively, located in the south of the Gaza Strip, in addition to the population in the Northern Governorate which is of about 335,253, and the Middle Governorate whose population is of some 247,150 inhabitants. The smallest governorate in terms of area is the Middle Governorate which is $55.19 \mathrm{~km}^{2}$, and then Rafah 
Fig. 1 Location of the Gaza Strip

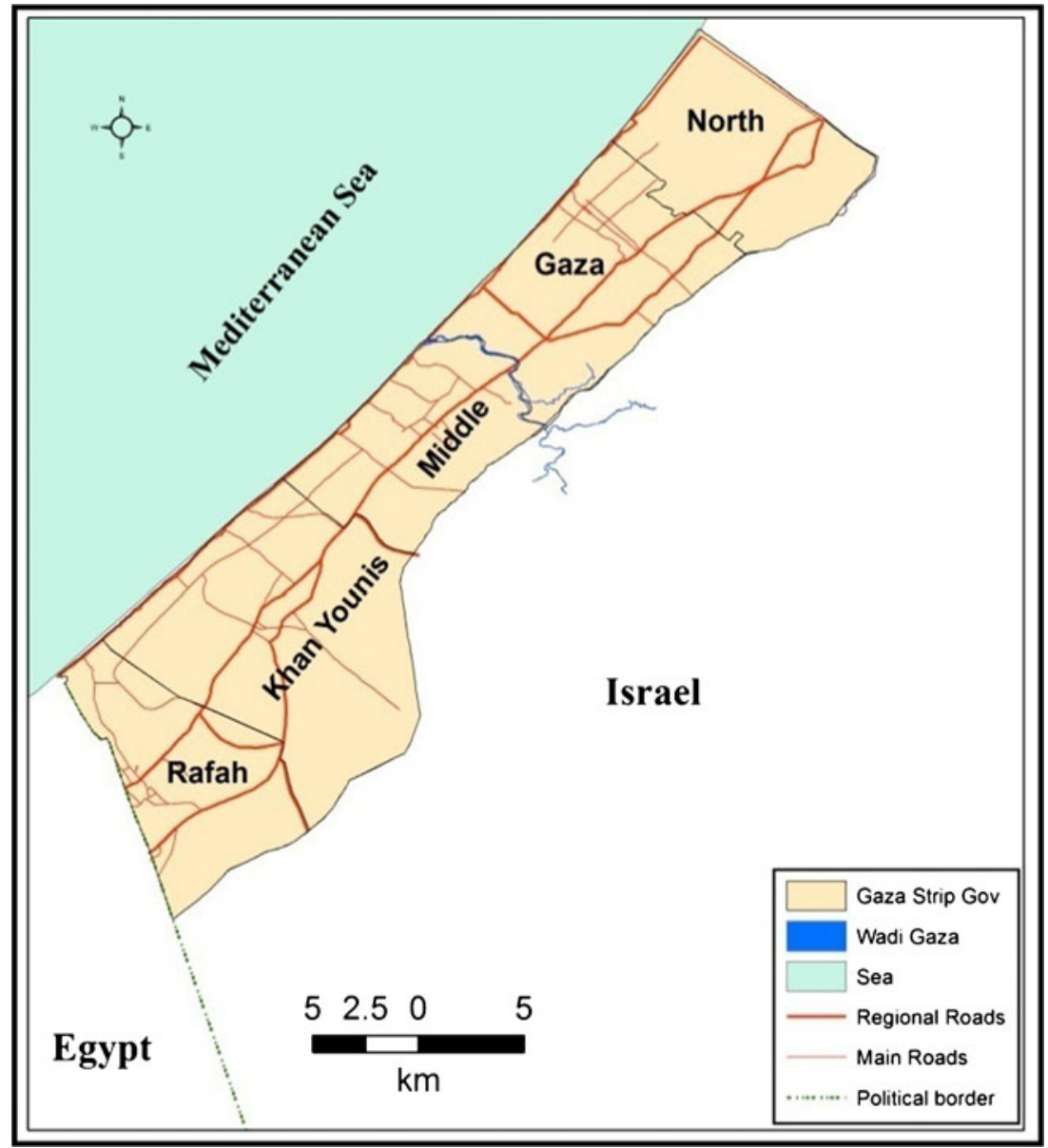

$\left(60.19 \mathrm{~km}^{2}\right)$, Northern Governorate $\left(60.66 \mathrm{~km}^{2}\right)$ and Gaza $\left(72.44 \mathrm{~km}^{2}\right)$, being Khan Younis the largest, with $111.61 \mathrm{~km}^{2}$ as shown in Fig. 1.

On the Gaza coastal plain, the original Saharo-Sindian flora has been almost completely replaced by farmland and buildings. Gaza comprises six main vegetation zones: the coastal littoral zone, the stabilised dunes and blown-out dune valleys, the Kurkar, alluvial and grumosolic soils in the northern part, the loessial plains in the eastern part, and three wadi (river) areas (UNEP 2006).

\section{Methodology}

The methodology of this study is based on the evaluation of land changes, land analysis, land change potential and land change simulation on the Gaza Strip using remote sensing and GIS as shown in the methodology in Fig. 2.

\section{Model of land use and data}

The spatial database has been elaborated using the historical Landsat images from 1972, 1982, 1990, 2002 and 2013
(Table 1). The images were rectified from the aerial photo of 2007 using Erdas Imagine 2013, then were interpreted depending on the visual interpretation mainly, and used a supervised and unsupervised classification for more control and interpretation. Therefore, these methods used generalised digitalisation to obtain more accurate urban database using ArcGIS 10.2 and the cell size of all dataset converted to $15 \times 15 \mathrm{~m}$. The database was checked before starting the analysis.

In this study, the whole Gaza Strip area is considered suitable for agriculture. Hence, the Gaza Strip is classified into two classes of land use and cover (LUC), which are urban and agricultural areas (non-urban areas). However, there are other land uses and land covers in the study area which were considered as agriculture in this study.

Five drivers are selected to simulate and predict the future urban area in 2023. The first driver is the distance from the main and regional roads of 2013. People prefer to stay in houses overlooking the roads as economical places. The second driver is elevation and the third one is slope. People prefer high places with fewer slopes as safe places from floods during rainfalls and temperate climate during summer. The fourth driver is a distance 
Fig. 2 Methodology flow chart of for land change analysis, potential and simulation

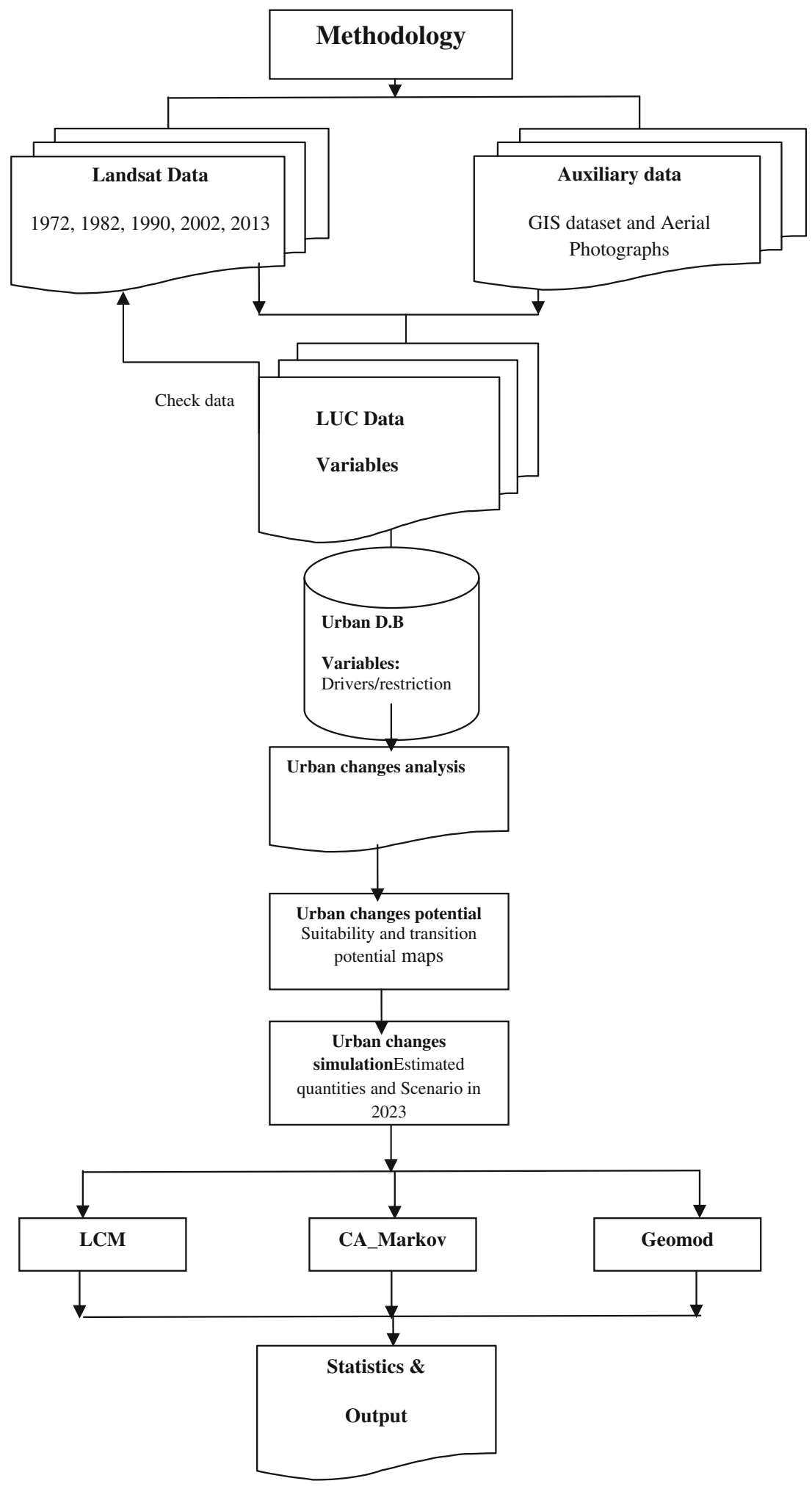

around urban area in 2013 because areas close to previous urban areas have better infrastructure and services and are safer during the invasion of the Israeli military. The fifth one is the buffer zone inside the Gaza Strip from the north and the east border line between the Gaza Strip and Israel that is considered a restricted area as people do not inhabit the border area given its dangerousness.

The buffer zone is of around $1 \mathrm{~km}$ in length which is selected as the average of distance between the eastern and northern border and the main street (Salah Eldin) on 
Table 1 Landsat data used in this study

\begin{tabular}{lll}
\hline Sensor & Row & Data type \\
\hline Landsat MSS & $188 / 38$ & $22 / 10 / 1972$ \\
Landsat 3 TM & $188 / 38$ & $13 / 08 / 1982$ \\
Landsat 5 TM & $174 / 38$ & $11 / 06 / 1990$ \\
Landsat 7 ETM+ & $175 / 38$ & $5 / 07 / 2002$ \\
Landsat 8 & $175 / 38$ & $25 / 06 / 2013$ \\
\hline
\end{tabular}

the one hand, and the distance between the border and the urban areas that are near the borders in the Gaza Strip on the other hand.

The quantitative measure of the variables' influence can be obtained by Cramer's V. A High Cramer's V value indicates that the potential explanatory of the variable is good but does not guarantee a strong performance since it cannot account for the mathematical requirements of the modelling approach used and the complexity of the relationship. However, it is a good indication that a variable can be discarded if Cramer's $\mathrm{V}$ is very low (Eastman 2012). The Cramer's V values are as follows: elevation 0.143 , slope 0.060 , roads 0.169 , distance to built-up 0.707 and border buffer 0.230 .

Cramer's V of the collection of factors is obtained in Land Change Modeler (LCM) before running multi-layer perceptron (MLP). The LCM includes include tools for the assessment and prediction of land cover change, and its implications are organised around major task areas: change analysis, change prediction and planning interventions (Eastman 2012).

MLP automatically evaluates and weights each factor and implicitly takes into account the correlations between the explanatory maps. All drivers are static. We also used Cramer's $\mathrm{V}$ to obtain the weights using the Saaty method under the analytical hierarchy process (AHP), and we introduced them in Geomod and in weighted linear combination (WLC) of MCE to obtain the suitability maps. This procedure is characterised by full trade-off between factors and an average level of risk, that means exactly midway between the minimisation (AND operation) and maximisation (OR operation) of areas to be considered suitable in the final result (Clark Labs 2012).

\section{Methodology for land change analysis, potential and simulation}

Three GIS models in Idrisi Selva software are selected for projection of the urban area in 2023, Geomod, Cellular Automata Markov (CA Markov) and Land Change Modeler (LCM), in addition to statistical estimation using the regression function to highlight the quantitative difference between the regression and Markov chain.
Figure 2 shows the methodology flow chart for land change analysis potential and simulation applied to the study area.

\section{Land change analysis}

The chronological series of LUC maps is analysed to detect changes. The LCM module provides quantitative assessment of category-wise land use changes in terms of net changes, swap, gains, losses and total changes (Eastman 2012), which are extracted from several pairs of dates, and the results are shown in maps and statistics. The change analysis was performed specifically between the images from 2002 and 2013, to understand the transitions of land use classes during the years. The CROSSTAB module of IDRISI was also used between two images to generate a cross-tabulation table in order to observe the consistency of images and distribution of image cells between the land use categories.

Besides, the statistics of the changes occurred in the area during different periods generated using a scatter diagram in Microsoft Excel.

\section{Land change potential: suitability and transition potential maps}

Two types of intermediate soft-classified maps, suitability maps and transition potential maps (Camacho Olmedo et al. 2013), are obtained for the land change potential study. Suitability maps are used in both CA_MARKOV and Geomod models; transition potential maps are used in the LCM model. The same driver maps are used in the Geomod, CA MARKOV and LCM models. A collection of factors are obtained from these drivers by the natural $\log$ transformation. The natural $\log$ transformation is effective in linearising distance decay variables (e.g. proximity to roads) (Eastman 2012).

GEOMOD creates the suitability image by computing for each grid cell a weighted sum of all the reclassified driver images (Pontius, 2006). Hence, the suitability in each cell is calculated according to the following:

$R(i)=\left[\sum_{a-1}^{A} W_{a} P_{a}\right] / \sum_{a-1}^{A} W_{a}$

where $R(i)=$ suitability value in cell $(i), a=$ particular driver map, $A=$ the number of driver maps, $W_{a}=$ the weight of driver map $a$, and $P_{a}(i)=$ percent developed in category $a_{\chi}$ of attribute map $a$, where $\operatorname{cell}(i)$ is a member of category $a_{x}$.

In CA_MARKOV, a suitability map may be produced from driver information or supplied (external), particularly by multi-criteria evaluation (MCE) (Paegelow and Camacho 2008). Each driver is considered a real number (\%). The 
Fig. 3 Urban areas from 1972 to 2013

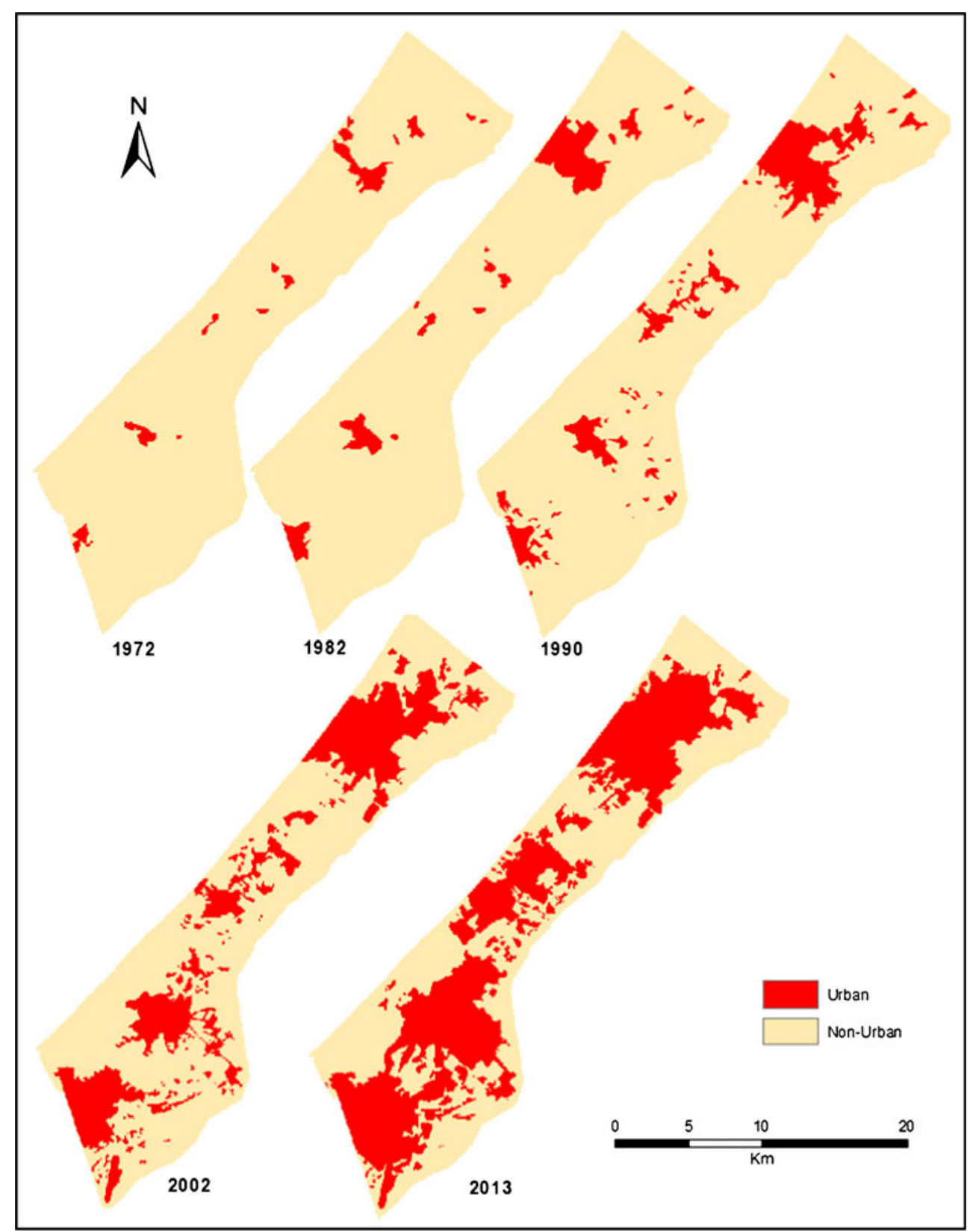

suitability maps for each LUC category are created by MCE, using all drivers converted to factors.

The transition potential maps are in essence potential maps for each transition in LCM. A collection of transition potential maps is organised within an empirically evaluated transition sub-model that has the same underlying driver variables. A transition sub-model can consist of a single land cover transition or a group of transitions that are thought to have the same underlying driver variables. These driver variables are used to model the historical change process. The transition potential maps are obtained by multi-layer perceptron (MLP) in LCM. The MLP option can run multiple transitions and undertakes the classification of remotely sensed imagery through the artificial neural network multi-layer perceptron technique, and it uses an algorithm to set the number of hidden layer nodes (Eastman 2012).

Table 2 Urban and non-urban areas from 1972 to 2013

\begin{tabular}{lllll} 
Year & Urban $\left(\mathrm{km}^{2}\right)$ & Urban $(\%)$ & Non-urban $\left(\mathrm{km}^{2}\right)$ & Non-urban (\%) \\
\hline 1972 & 10.94 & 3 & 349.06 & 96.96 \\
1982 & 25.29 & 7 & 334.71 & 92.98 \\
1990 & 46.88 & 12.8 & 313.12 & 86.98 \\
2002 & 100.23 & 27.4 & 259.77 & 72.16 \\
2013 & 166.29 & 46.2 & 193.71 & 53.81 \\
\hline
\end{tabular}




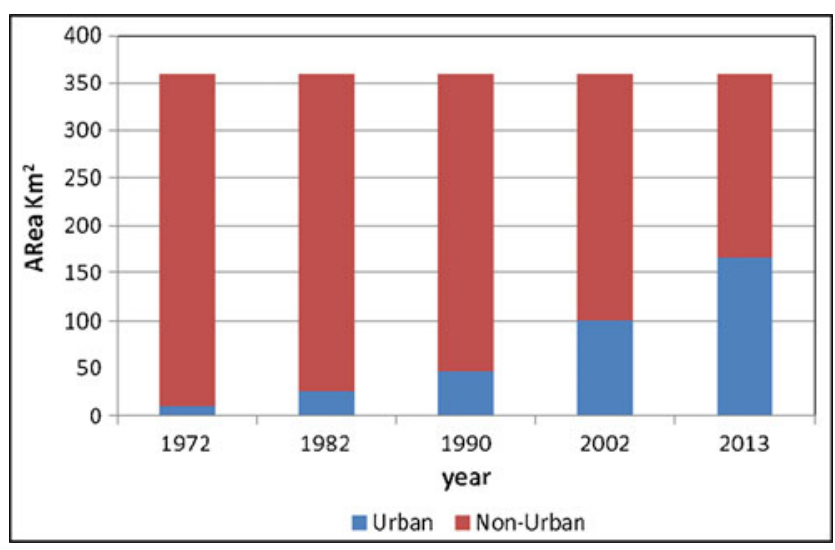

Fig. 4 Urban and non-urban areas from 1972 to 2013

\section{Land change simulation: the estimated quantities}

Markov chain analysis is used to calculate the estimated quantities in 2023 within urban data for the years 2002 and 2013, which is used in LCM model, CA MARKOV, and to calibrate the Geomod model.

CA_MARKOV and LCM incorporate the quantity of estimated change and persistence using a Markovian matrix. The MARKOV module computes the transition areas matrix and the transition probability matrix by cross-tabulation between LUC categories from two maps (t0 to $\mathrm{t} 1$ ), which reflect data from the calibration stage, to project the estimated changes and persistence at the simulation stage ( $\mathrm{t} 1$ to $\mathrm{T}$ ). The estimation to $\mathrm{T}$ is based on the number of time periods between $\mathrm{t} 0$ and $\mathrm{t} 1$ and the number of time periods between $\mathrm{t} 1$ and $\mathrm{T}$, respecting in any cases the same time units. A more detailed description of the MARKOV matrix can be found in the
IDRISI Selva Help System and also in Mas et al. (2014). The Markov chain analysis is one of the most widely used stochastic approaches in ecological and environmental modelling (Paegelow and Camacho 2008). For the study area, the estimated quantities in 2023 are based on the transitions during 2002-2013, using the MARKOV module of IDRISI. The same Markov transition probability matrix is used in both CA_MARKOV and LCM models.

Linear regression is applied as a method to compare the results of the Markov chain data. A regression uses the historical relationship between an independent (the dates) and a dependent variable to predict the future values of the dependent variable such as urban areas. The linear statistical regression was used for simulation of the built-up area for the year 2023 depending on the urban area in 1972, 1982, 1990, 2002 and 2013. The growth rate and other statistics were calculated using Microsoft Excel.

\section{Land change simulation: the scenario}

The three models are used to simulate likely urban areas in 2023 in a single scenario.

GEOMOD simulates the changes between exactly two categories, state 1 and state 2 (Eastman 2012), in our case study, urban and non-urban LUC. GEOMOD selects the location of the grid cells based on their suitability maps. The simulation can occur either forwards or backwards in time. The output result of Geomod is a byte binary image that shows the ending time.

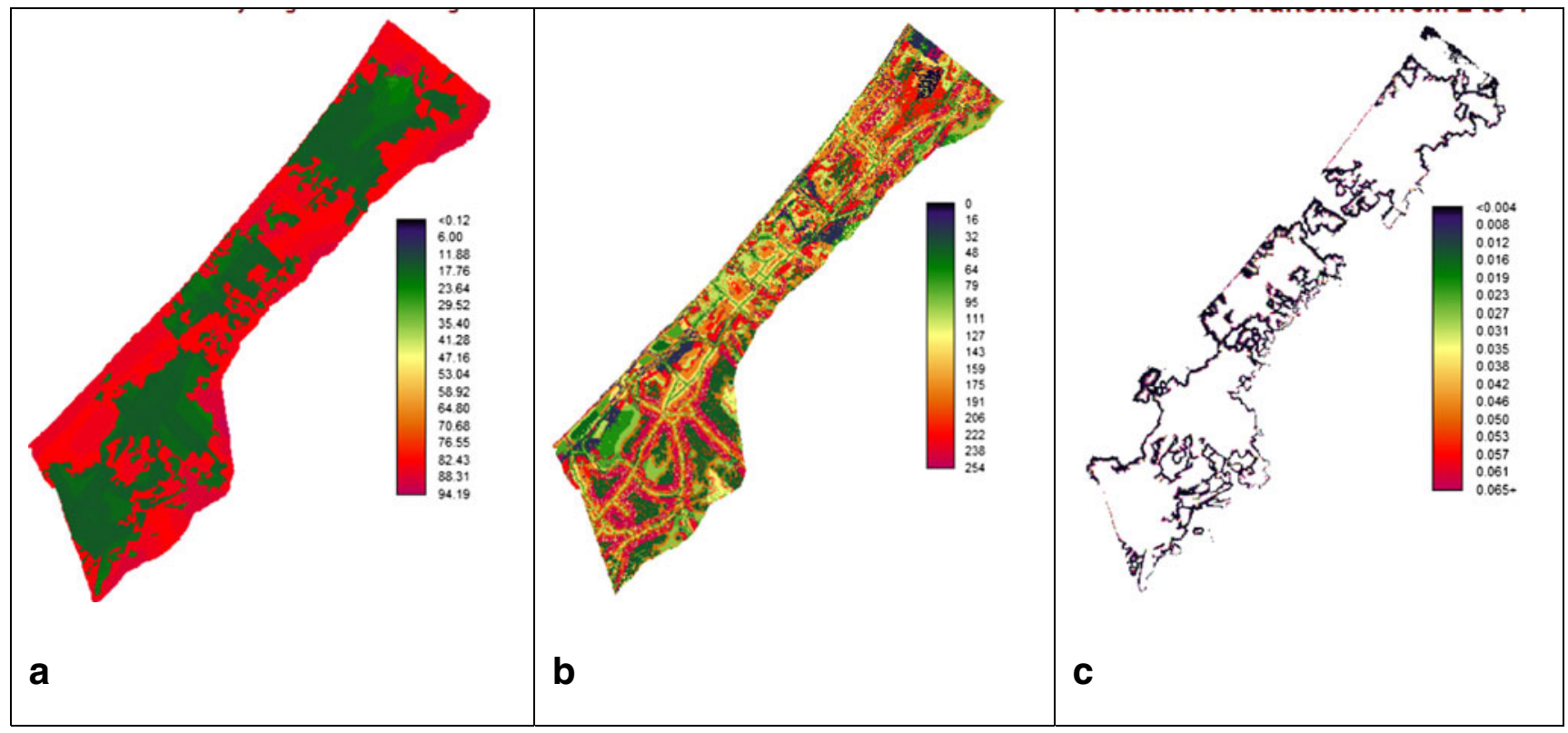

Fig. 5 a Geomod suitability map for urban area, b MCE suitability map for urban area for CA_MARKOV, $\mathbf{c}$ MLP transition potential map from nonurban to urban area for LCM 
Table 3 Transition area matrix for estimation of urban areas in the year 2023 by using 2002 and 2013 in cells and area $\left(\mathrm{km}^{2}\right)$

\begin{tabular}{lclll}
\hline Matrix & $\begin{array}{l}\text { Urban area } \\
\left(\mathrm{km}^{2}\right)\end{array}$ & $\begin{array}{l}\text { Non-urban } \\
\text { area }\left(\mathrm{km}^{2}\right)\end{array}$ & $\begin{array}{l}\text { Total area } \\
\left(\mathrm{km}^{2}\right)\end{array}$ & Percentage \\
\hline Urban & 166.29 & 0 & 166.30 & $\mathbf{4 6 . 1}$ \\
Non-urban & 46.05 & 148.59 & 194.64 & $\mathbf{5 3 . 9}$ \\
Total & 212.34 & 152.20 & 360.94 & $\mathbf{1 0 0}$ \\
Percentage & 58.83 & 42.17 & & 100 \\
\hline
\end{tabular}

The simulation of the Geomod model is based on the following (Clark Labs 2012):

1. Specification of the beginning time, ending time and time step for the simulation

2. An image showing the allocation of land use states 1 and 2 at the beginning time

3. A decision whether to constrain the simulated change to the border between state 1 and state 2

4. A map of suitability for the transition to land-use state 2,

5. The projected quantity of land-use states 1 and 2 at the ending time.

Both LCM and CA_MARKOV models use an a priori identical multi-objective land allocation (MOLA) to solve the concurrences between different uses or transitions. This process is based on the choice of the most suitable pixels, i.e. those with the greatest change potential in the ranked change potential maps. Through the Markov matrix, the MOLA creates a list of host classes (categories that will lose surface, in rows) and claimant classes (categories that will gain surface, in columns) for each host. The allocation is done for all claimant classes of each host class, and then it solves the conflicts based on a minimum-distance-to-ideal-point rule using the weighted ranks, and the final result is the overlay of each host class reallocation (Eastman et al. 1995; Mas et al. 2014).

Therefore, some differences exist in the MOLA algorithm in LCM and in CA MARKOV (Eastman 2012; Camacho
Olmedo et al. 2015). The MOLA works only once in the LCM procedure, while, in CA MARKOV, the MOLA runs once for each chosen iteration, that is the number of time units of the simulation period ( $\mathrm{t} 1$ to $\mathrm{T}$ ), and the final result is the overlay of each new simulation map after each MOLA reallocation. A second difference is that in CA MARKOV, cellular automata (CA) are used to obtain a spatial situation and distribution map; it means that CA transition rules use their current neighbourhood of pixels to estimate land use type in the future. The state of each cell is affected by the states of its neighbouring cells in the filter considered. Besides, using CA transition rules and land use transition is governed by maximum probability transition and will follow the constraint of cell transition that happens only once to a particular land use, which will never be changed further during simulation. For better comparing CA_MARKOV and LCM, in our case study, we used a non-filter (Camacho Olmedo et al. 2015), ignoring the cellular automata; therefore, the effect of contiguity disappeared.

A validation by congruence of models is applied. To measure the congruence of models and the individual model contributions, the three simulation maps of stability and changes from 2013, specifically the simulated urban stability and simulated urban growth from 2013, are intersected by the logical operator AND. The intersection score measures the congruence of models, and all supplementary contributions of the two model combinations (Geomod and LCM, Geomod and CA_Markov, CA_Markov and LCM) are calculated with the remaining individual contributions (Paegelow et al. 2014). That can help to analyse the spatial differences.

\section{Results}

\section{Land change analysis of chronological series of LUC maps}

The results showed a drastic change in the land cover and growth of the urban area from 1972 to 2013 as shown in
Fig. 6 The scatter plot for Urban area in square kilometres from 1972 to 2023 versus year from Markov chain 2002-2013, Markov chain 1972-2013 and regression analysis

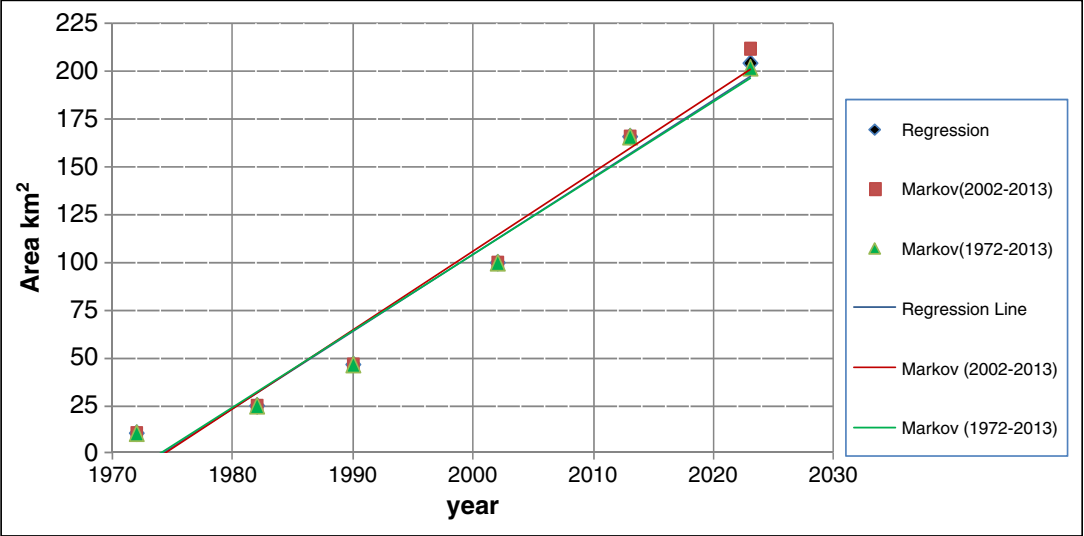


Table 4 The simulated urban area $\left(\mathrm{km}^{2}\right)$ in 2023 as a result of using different models

\begin{tabular}{lcccccccccc}
\hline Gov. & $\begin{array}{l}\text { Built. } 2002 \\
\left(\mathrm{~km}^{2}\right)\end{array}$ & $\begin{array}{l}\text { \% in } \\
2002\end{array}$ & $\begin{array}{l}\text { Built. } 2013 \\
\left(\mathrm{~km}^{2}\right)\end{array}$ & \% in 2013 & $\begin{array}{l}\text { Geomod } \\
\left(\mathrm{km}^{2}\right)\end{array}$ & $\begin{array}{l}\text { \% in 2023 } \\
\text { Geom }\end{array}$ & $\begin{array}{l}\text { CA-Markov } \\
\left(\mathrm{km}^{2}\right)\end{array}$ & $\begin{array}{l}\text { \% in 2023 } \\
\text { CA-Markov }\end{array}$ & $\begin{array}{l}\text { LCM } \\
(\mathrm{km})\end{array}$ & $\begin{array}{l}\text { \% in 2023 } \\
\text { LCM }\end{array}$ \\
\hline North & $\mathbf{1 7 . 2 9}$ & $\mathbf{4 . 8 0}$ & $\mathbf{2 4 . 0 7}$ & 6.69 & $\mathbf{3 1 . 8 9}$ & 8.86 & $\mathbf{3 0 . 6 1}$ & 8.50 & $\mathbf{3 0 . 5 9}$ & 8.50 \\
Gaza & $\mathbf{2 7 . 5 6}$ & $\mathbf{7 . 6 6}$ & $\mathbf{3 3 . 5 3}$ & 9.31 & $\mathbf{4 4 . 2 6}$ & 12.29 & $\mathbf{4 2 . 2 3}$ & 11.73 & $\mathbf{4 1 . 7 5}$ & 11.60 \\
Middle & $\mathbf{1 2 . 0 5}$ & $\mathbf{3 . 3 5}$ & $\mathbf{2 8 . 1}$ & 7.81 & $\mathbf{3 5 . 4 6}$ & 9.85 & $\mathbf{3 7 . 1 5}$ & 10.32 & $\mathbf{4 0 . 1 3}$ & 11.15 \\
K.Younis & $\mathbf{2 1 . 0 1}$ & $\mathbf{5 . 8 4}$ & $\mathbf{4 7 . 2}$ & 13.11 & $\mathbf{5 7 . 8 5}$ & 16.07 & $\mathbf{6 1 . 9 9}$ & 17.22 & $\mathbf{5 9 . 5 1}$ & 16.53 \\
Rafah & $\mathbf{2 2 . 3 0}$ & $\mathbf{6 . 1 9}$ & $\mathbf{3 3 . 3 7}$ & 9.27 & $\mathbf{4 2 . 8 8}$ & 11.91 & $\mathbf{4 0 . 3 8}$ & 11.22 & $\mathbf{4 0 . 3 4}$ & 11.21 \\
Total & $\mathbf{1 0 0 . 2 1}$ & $\mathbf{2 7 . 8 4}$ & $\mathbf{1 6 6 . 2}$ & 46.2 & $\mathbf{2 1 2 . 3}$ & 58.98 & $\mathbf{2 1 2 . 3}$ & 58.98 & $\mathbf{2 1 2 . 3}$ & 58.98 \\
\hline
\end{tabular}

Fig. 3, while the agricultural areas were converted to urban areas. This reveals the need for land use managers and city planners to understand future growth and plan further developments.

Urban areas are continuously increasing in time, whereas non-urban areas are decreasing represented by agricultural areas as shown in Table 2 and Fig. 4.

\section{Suitability maps/transition potential maps}

The auto-created suitability map run by the Geomod model shown in Fig. 5 was created depending on the factors of drivers. In Fig. 5b, the MCE suitability map for urban area is shown, which will be used in CA_MARKOV with the suitability map for non-urban area. A pixel completely within the urban area has the highest suitability value, and other pixels would have fewer suitability values depending on the included values. These suitability maps in Geomod and in MCE are obtained from the latest date in the calibration period for 2013.

The MLP neural network in LCM was used to obtain the transition potential map from non-urban to urban area as shown in Fig. 5 c, based on the real transition from the calibration period 2002-2013. The output map is the result of high weight of distance to built-up area (0.707 Cramer's value). We must remember that MLP automatically evaluates and weights each factor and takes into account the correlations between them. In Fig. 5c, the biggest density of cells with high values of transition potential is around the built-up area (low distance).

\section{The estimated quantities}

The Markov transition area matrix is based on land use changes without drivers, that is, each category will change to the other category. This matrix results from the multiplication of each column in the transition probability matrix by the number of cells of the corresponding land use in the last image for the year 2013. Rows represent land use in the calibration period in 2013and columns represent land use in the simulation date 2023. The matrix showed a transition area between two categories in cells or area $\left(\mathrm{km}^{2}\right)$ as shown in Table 3, which is used for the estimation of the urban area in 2023, based on the last period 2002-2013, that is, a past trend scenario, in Geomod, CA MARKOV and LCM.
Fig. 7 a Real map 2013 and simulated urban maps for the year 2023 as results of b Geomod, c CA_Markov, and d Land Change Modeler

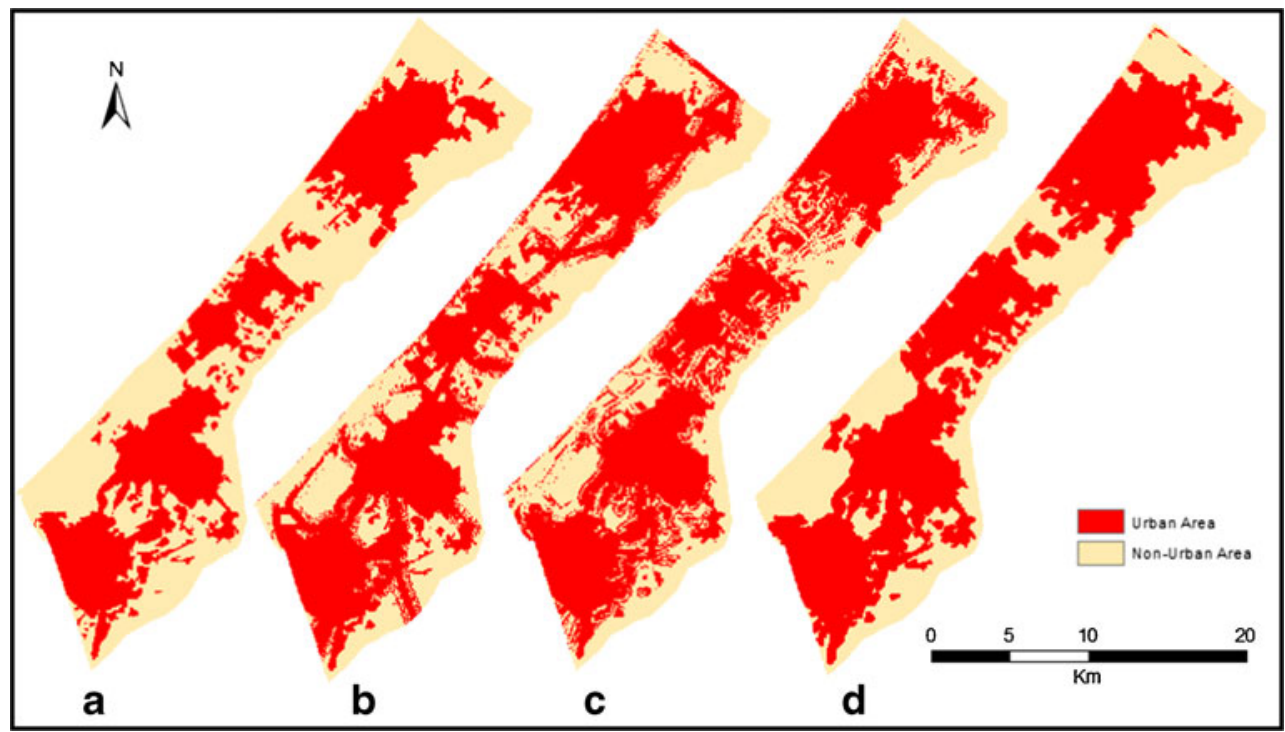


Fig. 8 Urban area for the years 2002, 2013 and 2023 for

Geomod, CA_Markov and LCM models

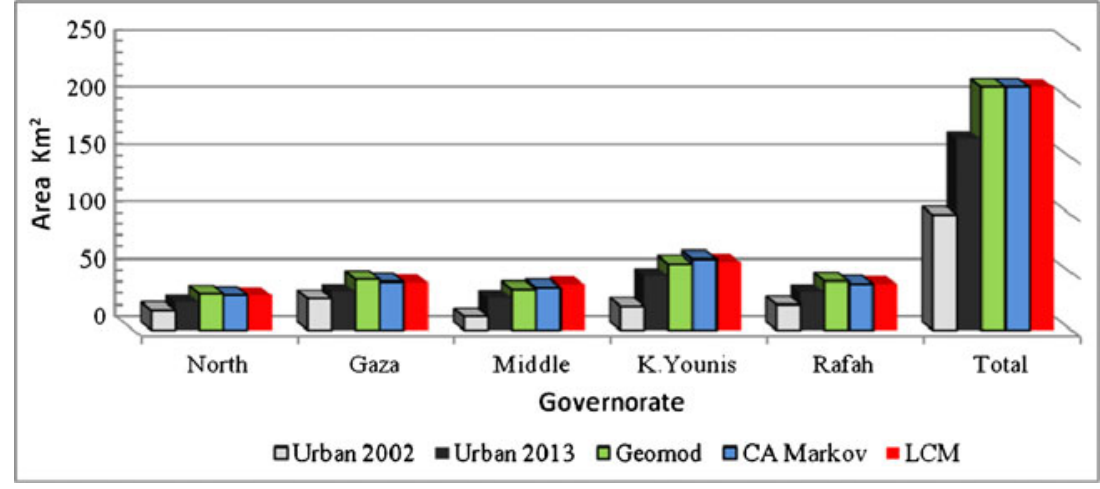

A regression analysis shows the historical relationship between the urban area versus a year to predict the future of urban area for the year 2023, that is 204.8.

Therefore, the adjusted $R^{2}$ is 0.97 and the equation of regression can be expressed as follows:

$y=4.5768 X-9054.022$

In Fig. 6, the scatter diagram shows the comparison between three past trend scenarios. The first one is the Markov chain from 2002-2013 to 2023, the second one is the Markov chain from 1972-2013 to 2023, and the third one is the regression line to 2023 depending on the basic data. That shows that $204.8 \mathrm{~km}^{2}$ of the projection of regression line is near $202.4 \mathrm{~km}^{2}$ of Markov chain line 1972-2013 to 2023, but the Markov chain line 2002-2013 to 2023 is clearer: $212.3 \mathrm{~km}^{2}$.

\section{Simulations maps: scenario to 2023}

The results of the simulation showed the same quantities in the three models according to the Markov chains, i.e. $212.3 \mathrm{~km}^{2}$, but variations were observed in the results of the three models
Fig. 9 Congruence of the three simulated maps by Geomod, CA MARKOV and LCM, specifically the simulated urban stability and simulated urban growth from 2013

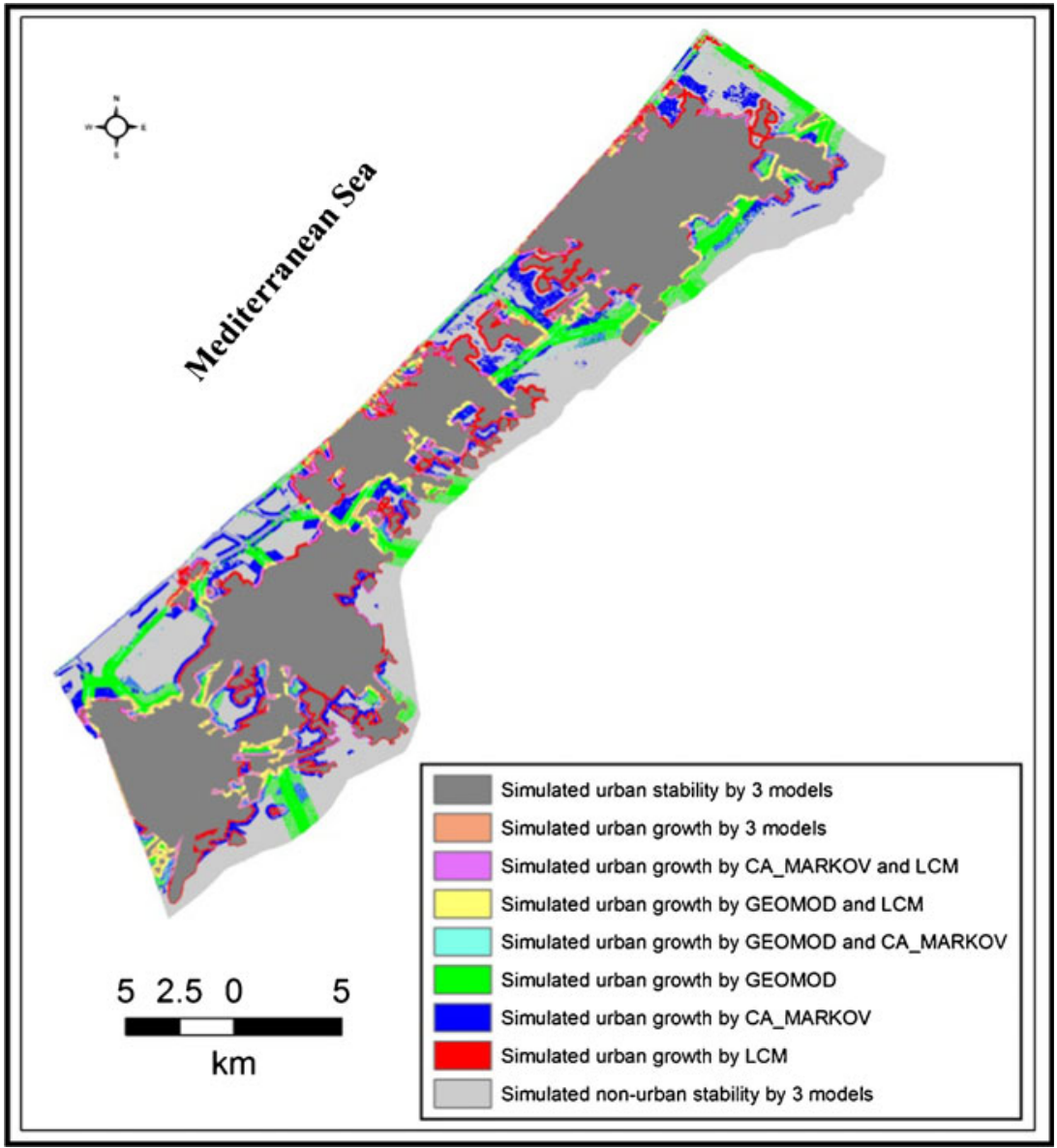


Table 5 Area $\left(\mathrm{km}^{2}\right)$ and percent of congruence of the three simulated maps by Geomod, CA MARKOV and LCM, specifically the simulated urban stability and simulated urban growth from 2013

\begin{tabular}{llrr}
\hline Class & Simulation & Area $\left(\mathrm{km}^{2}\right)$ & Percent \\
\hline 1 & Urban stability by 3 models & 166.2 & 46.2 \\
2 & Urban growth by 3 models & 5.7 & 1.58 \\
3 & Urban growth by CA_MARKOV and LCM & 10.8 & 2.99 \\
4 & Urban growth by GEOMOD and LCM & 11.1 & 3.07 \\
5 & Urban growth by GEOMOD and CA_MARKOV & 4.8 & 1.33 \\
6 & Urban growth by GEOMOD & 24.5 & 6.79 \\
7 & Urban growth by CA_MARKOV & 24.7 & 6.84 \\
8 & Urban growth by LCM & 18.5 & 5.12 \\
9 & Non-urban stability by 3 models & 94.6 & 26.20 \\
\hline
\end{tabular}

in the urban areas according to the five governorates of the Gaza Strip as shown in Table 4 and Fig. 7.

There are variations in the rate of urban expansion in each governorate. Figure 8 shows those differences.

Figure 9 and Table 5 show the result of congruence of the three simulated maps by Geomod, CA MARKOV and LCM, specifically the simulated urban stability, simulated urban growth from 2013, the area and percent of obtained classes from this map.

\section{Discussion}

This paper presents the results of analysing and simulating land use change by using the three GIS models.

The results of the past trend scenario of spatial distribution in 2023 presented some differences in Fig. 8; there are similarities in the allocation of urban area, both in Geomod and in CA Markov, and there are differences in LCM, where it is shown that the urban expansion covers $59 \%$ of the area. The results of the three models are located spatially near urban 2013. This clearly makes sense given that buildings are usually constructed and money is usually invested around main roads beside the urban areas. Otherwise, Geomod expands clearly near the roads that have been noticed in the north area near the border in the restricted area (buffer zone driver).

Differences have been noticed in the spatial distribution of all models in each Governorate. In KhanYounis and Middle Governorates from Table 4 and Fig. 10, the percentage of urban area from 2002 to 2013 has grown by more than $100 \%$.The Israeli withdrawal from the Gaza Strip in 2005, and leaving the settlements are the main reasons which restrain urban growth in these two governorates; the settlements in these governorates had an area of around $40-50 \%$ of the total area in Rafah and Khanyounis, which does not allow natural growth. After the Israeli withdrawal, the population began to immigrate to those areas after the people had left them because of barrier settlements, and also the price of land is cheaper than in the northern areas. In addition to this, the government housing projects were internationally supported.

In Fig. 10, the Gaza Governorate has fewer urban areas with high population as compared to Rafah and others. This is due to the vertical urban buildings that house a high proportion of the population.

The data analysis shows an increase in the urban area10.9 (1972), 25.3 (1982), 46.9 (1990), 100.2 (2002), 166.3 (2013) and $212.3 \mathrm{~km}^{2}$ (2023) - which constitutes the average area percentage from all simulations of the whole Gaza Strip,
Fig. 10 The population and urban areas from 2013 to 2023

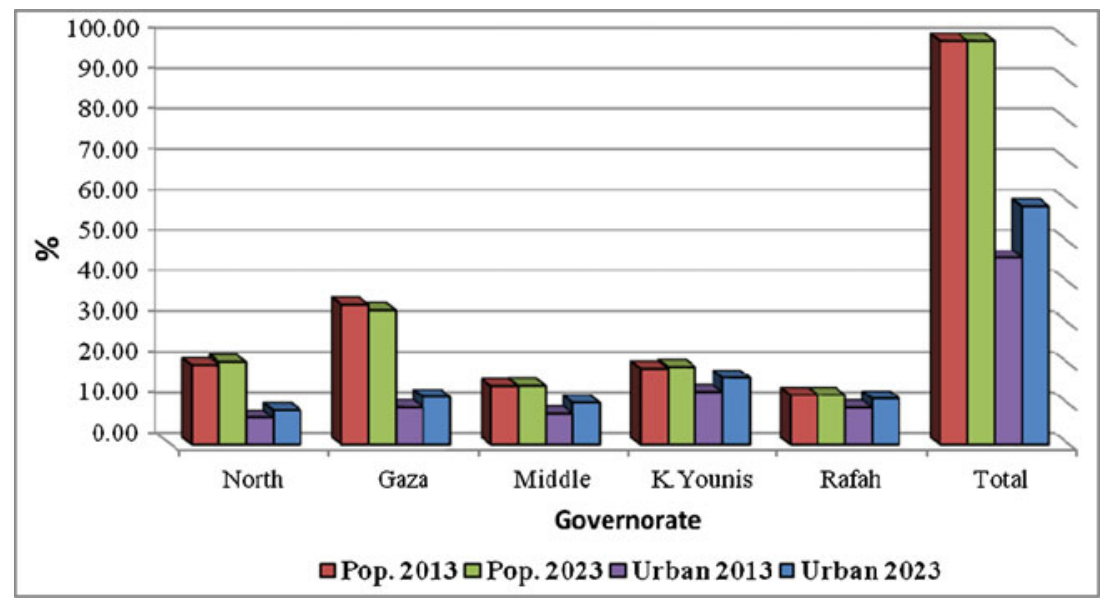


Fig. 11 Growth of the urban area in governorates from 1972 to 2023

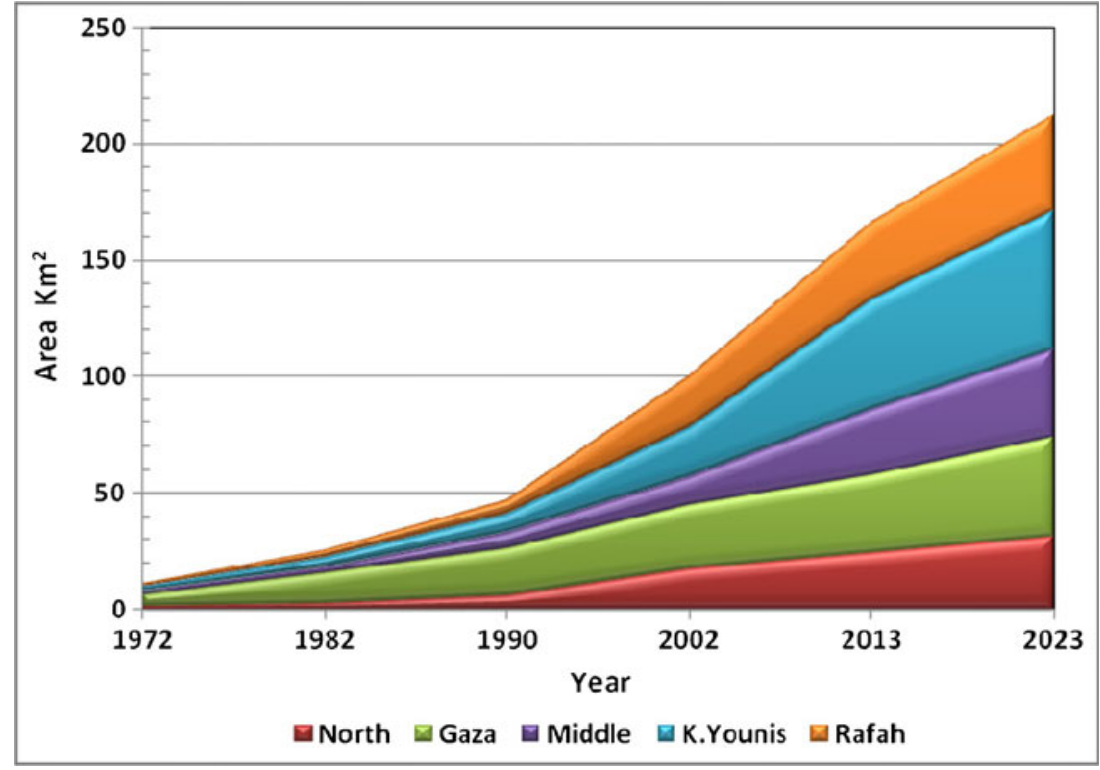

i.e. around $58.8 \%$. Figure 11 illustrates the increase in the urban area and the same is listed in Table 6.

Table 6 shows that urban expansion is positively correlated with population growth. So the density of population in the Gaza Strip will increase from 4661.5 in 2013 to 6704.3 inhabitants per square kilometre in 2023 . However, the actual density of population is 10,231.1 in 2013 and 11,526.4 inhabitants per square kilometre in 2023, because most Gazans live in urban areas, which is considered one of the highest population densities in the world.

The study results showed that there is a decrease in the agricultural land (non-urban area), which will continue with growth of population in absence of management and planning. The study shows a rapid urban growth rate in each time period 1972-1982, 1982-1990, 1990-2002, 2002-2013 and 20132023, which are consequently $1.4,2.7,4.4,6$, and $3.8 \mathrm{~km}^{2}$. This will continue in decreasing of agricultural areas as seen in Table 7 .

During the period from 1972 to 2000, the Palestinian economy in the Gaza Strip grew parallel to the Israeli economy. From 1972 until the eruption of the first Intifada (uprising) in 1987, there was a dramatic rise in the Palestinian standard of living. The main reason for that rise was the opening of the

Table 6 Increase of the urban area from 1972 to 2023

\begin{tabular}{llcc}
\hline Year & Population no. & $\%$ area & Area $\left(\mathrm{km}^{2}\right)$ \\
\hline 1972 & 393,800 & 3.0 & 10.9 \\
1982 & $511,115.2$ & 7.0 & 25.3 \\
1990 & 642,814 & 12.8 & 46.9 \\
2002 & $1,182,908$ & 27.4 & 100.2 \\
2013 & $1,701,437$ & 46.2 & 166.3 \\
2023 & $2,447,054$ & 58.8 & 212.3 \\
\hline
\end{tabular}

rapidly expanding Israeli job market to Palestinian workers (Swirski 2008). The situation continued until the signing of the 1993 Oslo Accords. From 1994 to 2000, there were huge urban projects and many investments leading to urban expansion.

After the conflicts from 2000 to 2013, the Palestinian workers in Israel became unemployed, in addition to the siege that started in 2007 around the Gaza strip, which prevented the urban expansion from keeping the same growth rate as in previous periods. From 1972 to 1994, urbanisation distibuted more vertically than horizontally, and the situation reversed after the period 1994 to 2013.

The simulation of land uses in the year 2023 clearly shows that the urban area increased rapidly due to the high population growth rate and to the lack of management and future planning. The master plan of the Gaza Strip was developed by the Ministry of Planning that did not take into account land degradation and rapid growth, and to take other directions including vertical urban construction as a policy to raise public awareness.

In addition, the power is necessary to support laws and legislations through tighter regulation and implementation of laws on sold lands by the owners as well as governmental lands, development of the master plan based on the temporal

Table 7 The annual growth of urban areas per period

\begin{tabular}{ll}
\hline Period & $\begin{array}{l}\text { The annual } \\
\text { growth }\left(\mathrm{km}^{2}\right)\end{array}$ \\
\hline $1972-1982$ & 1.4 \\
$1982-1990$ & 2.7 \\
$1990-2002$ & 4.4 \\
$2002-2013$ & 6 \\
$2013-2023$ & 4.6 \\
\hline
\end{tabular}


scenario and finding a solution for the Palestinian political situation in the Gaza Strip.

Figure 9 and Table 5 show the probability trend of urban expansion in most areas that are high, and the simulated nonurban stability is $26.2 \%$. The results are obtained from different models that are important to the decision-maker and give a full visual for the future of urban growth in the Gaza Strip. The differences in these results provide different future simulations for the Gaza Strip, which will affect water quality and quantity as well as land and food security.

The research deals with the situation as for the year 2013, before the war on the Gaza Strip that started on 8 July 2014 and ended on 28 August 2014.

Shelter Cluster, co-chaired by the UN Refugee Agency and the Red Cross, estimates that under current conditions, it will take approximately 20 years to import the aggregates required to complete the housing reconstruction. This time frame is based on the current operational capacity of Kerem Shalom crossing for aggregates (100 truckloads daily), and the estimated 97,334 housing units required in the Gaza Strip (Shelter Palestine 2014).

The report of UNDP about war 2007/2008 1 year after, 2009 , mentioned that three quarters of the damage inflicted on buildings and infrastructure remains unrepaired and unreconstructed, and at least 6268 homes were destroyed or severely damaged. The civilian population suffered further from damage to electricity, water and sewage systems (UNDP 2009). In 2012, most buildings and infrastructure were rebuilt and returned to the natural growth. The Cairo Donor Conference took place on 12 October 2014. More than USD 5.4 billion were pledged by international donors in support of the plan to rebuild the Gaza Strip.

After the 2014 war on the Gaza Strip, the following scenarios can be envisaged:

- The siege will continue up to 2023, and then there will be no reconstructions and there will be a shortage of the urban areas as compared to 2013.

- The siege could come to an end with a political solution, and two scenarios could be possible:

- Rebuilding of what was destroyed in 2014 only and no noticeable increase will take place as compared to 2013.

- Rebuilding of what was destroyed in 2014, added to the needs of natural population growth, which will go in the aspects of three models by the year 2023 .

\section{Conclusions}

This paper presents, evaluates and simulates urban expansion using the historical and free Landsat data from 1972 to
2013.These simulations are based on the continuity of observed past trends and are not predictions, but a plausible scenario of future state underlying the maintenance of macro-political and social conditions.

The following conclusions were drawn from the results of this research about urban expansion simulation for the year 2023 using three land change models:

- The percentage of urban area will be around $58.8 \%$ of the Gaza Strip.

- There are differences in the spatial distribution of each model from place to place.

- In terms of services and management of the Gaza Strip, planners should take into account that there are going to be three blocks instead of many urban areas.

- Urban expansion will lead to dramatic changes and more stress on the agricultural areas, soil erosion and water quality and quantity.

- The increase of agricultural land and pressure on natural resources in the Gaza Strip will contribute to the local and global climate change.

Acknowledgments The authors are grateful to the Spanish MINECO and FEDER for supporting this work through the following project: Simulaciones geomáticas para modelizar dinámicas ambientales II. Horizonte 2020. 2014-2017. BIA2013-43462-P.

Open Access This article is distributed under the terms of the Creative Commons Attribution 4.0 International License (http:// creativecommons.org/licenses/by/4.0/), which permits unrestricted use, distribution, and reproduction in any medium, provided you give appropriate credit to the original author(s) and the source, provide a link to the Creative Commons license, and indicate if changes were made.

\section{References}

Alcamo J, Kok K, Busch G, Priess J (2008) Searching for the future of land: scenarios from the local to global scale. In: Alcamo J (ed) Environmental futures: the practice of environmental scenario analysis. Elsevier, Amsterdam, The Netherlands

Bayramoglu Z, Gundogmus E (2008) Farmland values under the influence of urbanization: case study from Turkey. J Urban Plan Dev Asce 134(2):71-77

Biggs TW, Atkinson E, Powell R et al (2010) Land cover following rapid urbanization on the US-Mexico border: implications for conceptual models of urban watershed processes. Landsc Urban Plan 96(2):7887

Camacho Olmedo MT, Paegelow M, Mas JF (2013) Interest in intermediate soft-classified maps in land change model validation: suitability versus transition potential. International Journal of Geographical Information Science, 27(12): 2343-2361. Taylor \& Francis. http:// dx.doi.org/10.1080/13658816.2013.831867

Camacho Olmedo MT, Pontius RG Jr., Paegelow M, and Mas JF (2015) Comparison of simulation models in terms of quantity and allocation of land change. Environmental Modelling \& Software, 69 (2015), 214-221. Publisher By: Elsevier. doi:10.1016/j.envsoft. 2015.03.003

Clark L (2012) IdrisiSelva help system. Clark University, USA 
Curran PJ (1985) Principles of Remote Sensing. In: Remote Sensing Today. Longman Scientific \& Technical, London

Eastman JR, Jin W, Kyem W, Toledano P (1995) Raster procedures for multi-criteria? Multi-objective decisions. Photogramm Eng Remote Sens 61(5):539-547

Eastman JR (2012) IdrisiSelva tutorial. Clark University, Worcester

EnnabWR (1994) Population and Demographic Developments in the West Bank and Gaza Strip until 1990. UNCTAD, Geneva

Forman RTT (1995) Land mosaics: the ecology of landscapes and regions. Cambridge University Press, Cambridge

Fung T (1990) An assessment of TM imagery for land-cover change detection. IEEE Trans Geosci Remote Sens 28:681-684

Gerylo GR, Hall RJ, Franklin SE, Moskal LM (2000) Estimation of forest inventory parameters from high spatial resolution airborne data. In: Proceedings of 2nd International Conference on Geospatial Information in Agriculture and Forestry, Colorado Springs, CO, March 2000

Goodchild MF (2005) GIS and modeling overview. In Maguire DJ, Batty M, and Goodchild MF, editors, GIS, Spatial Analysis, and Modeling. Redlands, CA: ESRI Press: 1-18 [414]

Han J, Hayashi Y, Cao X et al (2009) Evaluating land-use change in rapidly urbanizing China: case study of Shanghai. J Urban Plan Dev 135(4):166-171

Hualou L, Guoping T, Xiubin L (2007) Heilig GK (2007) Socioeconomic driving forces of land-use change in Kunshan, the Yangtze River Delta economic area of China. J Environ Manag 83:351-364

Janssen LLF (1993) Methodology for Updating Terrain Object Data from Remote Sensing Data: The Application of Landsat TM Data with Respect to Agricultural Fields. Dissertation Agricultural University, Wageningen

Jat MK, Garg PK, Khare B (2008) Monitoring and modelling of urban sprawl using remote sensing and GIS techniques. Int J Appl Earth Obs Geoinformatic 10(1):26-43

Lambin EF, Turner BL II, Geist $\mathrm{H}$ et al (2001) The causes of land-use and land-cover change: moving beyond the myths. Glob Environ Chang 11(4):261-269

Lee D, Choe H (2011) Estimating the impacts of urban expansion on landscape ecology: forestland perspective in the Greater Seoul metropolitan area. J Urban Plan Dev-Asce 137(4):425-437

Mas JF, Kolb M, Paegelow M, Camacho Olmedo MT, Houet T (2014) Inductive pattern-based land use / cover change models: A comparison of four software packages. Environmental Modelling \& Software 51(2014): 94-111. Elsevier. http://dx.doi.org/10.1016/j. envsoft.2013.09.010

MedWetCoast (2003) Management plan: Wadi Gaza, Project for the Conservation of Wetland and Coastal Ecosystems in the Mediterranean Region

Nakicenovic N, Swart R (eds) (2000) IPCC Special Report on Emission Scenarios. Cambridge University Press, Cambridge, UK

Nunes C, Augé JI (eds) (1999) Land-use and land-cover change: implementation strategy. IGBP Report No. 48 and IHDP Report No. 10, IGBP, Stockholm

Paegelow M, Camacho Olmedo MT (2008) Modelling environmental dynamics. Advances in Geomatic simulations. Series Environmental Science. Springer Verlag, Heidelberg. ISBN: 9783-540-68489-3
Paegelow M, Camacho Olmedo MT, Mas JF, Houet T, Pontius RG Jr. (2013) Land Change Modelling: moving beyond projections. International Journal of Geographical Information Science, vol. 27 (9): 1691-1695. Taylor \& Francis. http://dx.doi.org/10.1080/ 13658816.2013.819104

Paegelow M, Camacho Olmedo MT, Mas JF, Houet T (2014) Benchmarking of LUCC modelling tools by various validation techniques and error analysis. Cybergeo: Eur J Geogr [En ligne], Systèmes, Modélisation, Géostatistiques, document 701, mis en ligne le 22 décembre 2014. ISSN: 1278-3366. URL: http:// cybergeo.revues.org/26610; doi:10.4000/cybergeo.26610

Palestinian Central Bureau of Statistics (PCBS) (2013) Statistical Yearbook of Palestine 2013, No 14. Ramallah - Palestine

Palestinian Ministry of Agriculture (MOAg) (2013) Unpublished material and statistical data

Palestinian Ministry of Environmental Affairs (MEnA) (1999) Environmental National Strategy, MEnA

Peterson GD, Cumming GS, Carpenter SR (2003) Scenario planning: a tool for Conservation in an uncertain world. Conserv Biol 17:358366

Raskin P, Gallopin G, Gutman P, Hammond A, Swart R (1998) Bending the curve: toward global sustainability. A Report to the Global Scenario Group, PoleStar Series Report No. 8. Stockholm Environment Institute, Stockholm, Sweden

Shelter Palestine, Shelter Cluster Palestine Gaza Response Update (2014) Coordinating Humanitarian Shelter. www.ShelterPalestine.org and www.ShelterCluster.org. Accessed 15 Oct 2014

Sleeter BM, Sohl TL, Bouchard M, Reker R, Sleeter RR, Sayler KL (2012) Scenarios of land use and land cover change in the conterminous United States -Utilizing the Special Report on Emission Scenarios at ecoregional scales: Global Environmental Change at http://dx.doi.org/10.1016/j.gloenvcha.2012.03.008

Swart RJ, Raskin P, Robinson J, (2004) The problem of the future: sustainability Science and scenario analysis. Glob Environ Chang 12: $137-146$

Swirski S (2008) The Burden of Occupation. The Cost of the Occupation to Israeli Society, Polity and Economy. Adva Center, Tel Aviv

UNDP (2009) One Year After Report (Gaza Early Recovery and Reconstruction Needs Assessment) United Nations Development Programme

UNEP (2003) Desk study on the environment in the occupied Palestinian Territories. United Nations Environment Programme

UNEP (2006) Environmental Assessment of the Areas Disengaged by Israel in the Gaza Strip. United Nations Environment Programme

UNEP (2009) Environmental Assessment of the Gaza Strip following the escalation of hostilities in December 2008-January 2009. United Nations Environment Programme

\section{Further Reading}

Pontius Jr. RG, Chen H (2006) GEOMOD Modeling. Chapter of help system in J Ronald Eastman. Idrisi 15: The Andes Edition. Worcester MA: Clark Labs, Clark University 